\title{
THE EMISSION POTENTIAL FROM MUNICIPAL SOLID WASTE LANDFILL IN JORDAN
}

\author{
Mohammad Aljaradin', Kenneth M. Persson² \\ 1 Department of Natural Resources and Chemical Engineering, Tafila Technical University, Jordan, e-mail: \\ mohammad.aljaradin@ttu.edu.jo \\ 2 Division of Water Resources Engineering, Lund University, Sweden, e-mail: kenneth_m.persson@tvrl.Ith.se
}

Received: 2015.11 .18

Accepted: 2015.12 .09

Published: 2016.01.06

\begin{abstract}
A comprehensive study was conducted to monitor the emission potential from solid waste landfilled in Jordan over a period of 292 days using an anaerobic lysimeter. A 30 $\mathrm{kg}$ waste sample reflecting the typical municipal solid waste (MSW) streams generated in Jordan was used to simulate the influence of climate on the emission potential of landfills located in semi-arid areas. The experimental results demonstrated that a significant amount of leachate and landfill gas was produced. The methane content was found to be more than $45 \%$ and the leachate produced reached 15.71 after 200 days. However, after 260 days the gas and leachate production rate became negligible. A significant amount of heavy metal traces was found in the leachate due to mixed waste disposal. Changes in biogas and leachate quality parameters in the lysimeter revealed typical landfill behaviour trends, the only difference being that they developed much more quickly. In view of current landfill practices in Jordan and the effect of climate change, the results suggest that landfill design and operational modes need to be adjusted in order to achieve sustainability. For this reason, optimized design parameters and operational scenarios for sustainable landfill based on the country's climatic conditions and financial as well as technical potential are recommended as a primary reference for future landfills in Jordan as well as in similar regions and climates.
\end{abstract}

Keywords: landfill emissions, climate change, green energy, Jordan.

\section{INTRODUCTION}

Landfills in semi-arid climatic areas have not been well studied. The literature contains very limited information on the interaction between a dry climate and the composition of landfill emissions (landfill gas and leachate), which constitutes one of the major challenges of sustainable landfill design and operation. Biodegradability of municipal solid waste (MSW) differs greatly from place to place; its production and composition are influenced by climate, season, cultural practice, co-disposal of waste water, etc. For example, the probability of a high discharge of leachate at certain times of the year makes leachate treatment very complex. As a result, leachate collection systems and treatment have to be designed to cope with the maximum concentration of pollutants, while taking account of climatic factors. In general, field investigations of landfills in semi-arid climates should be carried out to gather practical and reliable data, particularly gas production rates, leachate quality and degradation processes. However, simulating and predicting emissions from MSW landfills by constructing and operating landfill test cells or large scale lysimeters is timeconsuming, costly and difficult to control, while in many cases it is not easy to obtain representative data in a real landfill. Therefore, laboratory scale lysimeters are often used to simulate waste degradation behaviour in landfills [Barlaz et al., 1987; Barlaz et al., 1989b; Barlaz et al., 1989a; Stegmann, 1997], as they make it possible to vary parameters and study the influence of both aerobic and anaerobic processes. Youcai et al. [2002] stated that when the scale is sufficiently large, 
laboratory scale lysimeters to simulate a landfill in terms of trends are applicable, reasonable and reliable. However, the exact parameter values in real landfills should be monitored and the data obtained in situ. Therefore, lysimeter studies are generally conducted to verify the reliability of the results [Barlaz et al., 1989]. A lysimeter study was undertaken to determine the quantities of moisture and air that would optimize degradation, which can be enhanced by the application of water, the recycling of leachate and the addition of air [Stessel and Murphy, 1992]. Stegmann [1997] presented a landfill simulation technique using 1001 volume laboratory scale containers, where the processes can be controlled and reproducible results including mass balances obtained. Sufficiently large-scale lysimeter studies of waste are considered reasonable and reliable simulations of landfill conditions as they produce leaching patterns similar to field conditions. However, some results suggest that leachate emissions from full-scale landfill decrease more rapidly than predicted by laboratory experiments [Fellner et al., 2009]. The limitations of lysimeter studies have been widely discussed and although they never totally reflect full-scale landfill operation [Tränkler et al., 2005], they can help to provide a better understanding and reduce the cost, time, labour and complexities of field studies [Tränkler et al., 2005; Youcai et al., 2002; Kylefors et al., 2003].

In this work, lysimeter experiments were designed to obtain primary information about the major environmental concerns involved in MSW landfill design for sustainable solid waste management in a semi-arid climate, namely the quantity and quality of leachate, gas generation and decomposition processes. A representative Jordanian MSW sample was used to determine the quantity and quality of landfill emissions and their impact on the environment. Environmental data from El-Akader, the biggest landfill in Jordan, were used for simulating rainfall and temperature in the lysimeter. Results from the lysimeter tests are intended to improve design parameters and operational methods for landfilling in Jordan, with the ultimate goal of making recommendations for sustainable landfill operation, taking account of current landfill practices in the country and the effect of climate change.

\section{MATERIAL AND METHODS}

\section{Apparatus}

A 1001 volume stainless steel lysimeter was built as a reactor in accordance with the original design of Ritzkowski and Stegmann [2003]. The internal diameter and height of the reactor were 0.40 and $1.00 \mathrm{~m}$, respectively. A perforated plate was installed at the bottom to prevent clogging, loss of waste and to drain the leachate generated. The latter was collected in a transparent container equipped with a pump for recirculation and sampling. A port for leachate sampling and water addition was installed in conjunction with the leachate recirculation line, beside which a tube for pressure balance was connected between the reactor and the leachate container. A leachate irrigation line was installed at the top of the reactor to distribute the leachate to the waste mass. A rubber gasket was placed between the flange and the top lid in order to make it gas tight. A gas sampling port was installed on the lid of the reactor and connected to a volumetric gas counter. In front of the gas counter, a membrane filter $(0.45 \mu \mathrm{m})$ was connected to the line to trap any moisture in the gas (see Figure 1). The lysimeter enables leachate recirculation, rainfall simulation, leachate col-

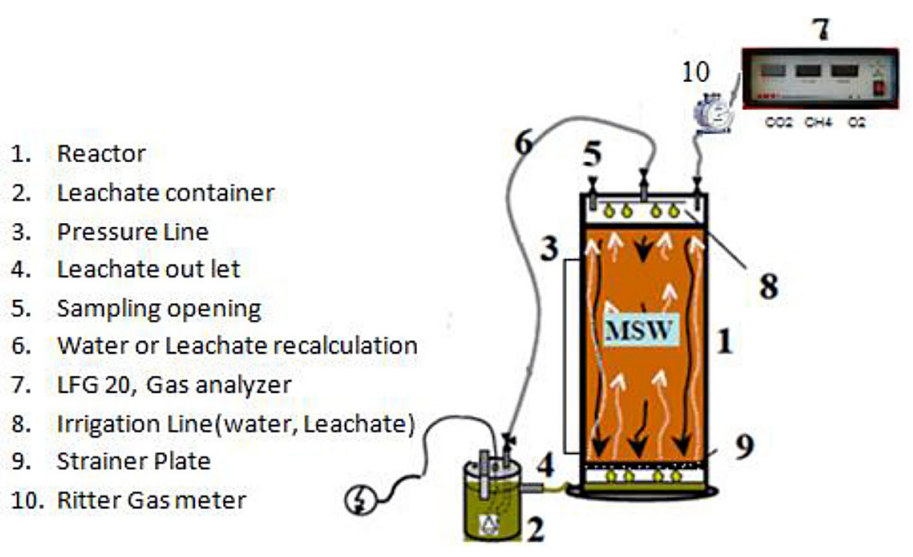

Figure 1. The mini landfill (lysimeter) 
lection and measurements of biogas content and volumes.

\section{Experimental operation}

To simulate Jordanian solid waste, $30 \mathrm{~kg}$ of wet waste from Jordan with an average moisture content of $52 \%$ was used in the lysimeter. In Figure 2 , the composition of the waste is presented. The waste reflects typical MSW generated in Jordan.

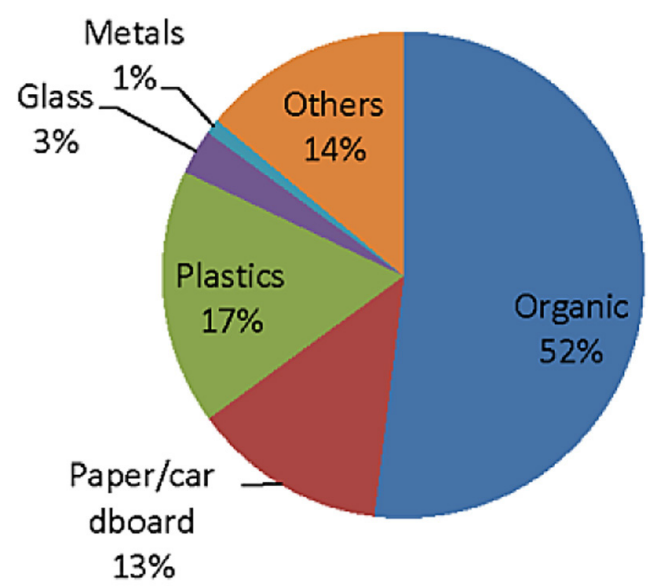

Figure 2 The physical composition of the waste used in the lysimeter

The waste was shredded to $3-5 \mathrm{~cm}$ to achieve a relatively homogeneous mixture and enhance the degradation process. The waste was selected to be typical of Jordanian solid waste as presented by SWEEP [2010]. To ensure anaerobic conditions inside the closed lysimeter, it was flushed with pressurized nitrogen gas for 30 minutes during the start-up phase. The lysimeters were operated under various controlled moisture content and temperature conditions; the leachate recirculation process was applied to the lysimeter, while temperature control was based on the climatic conditions in Jordan (see Table 1). The experiment was carried out under optimum temperature conditions, corresponding to the mean temperature at the site. In their study to determine the time it takes to achieve stabilization of solid waste in landfills in Jordan, Abu Qdais et al. [2008] found that the optimal conditions for solid waste biodegradation were a mesophilic temperature of around $38{ }^{\circ} \mathrm{C}$ and a moisture content of approximately $65 \%$. Based on these results, the temperature for dry and semi dry seasons was set to $35-38^{\circ} \mathrm{C}$. Temperature management was accomplished by incubating the lysimeter with controlled electrically heated water baths.
The experimental work was conducted in four stages, each of which involved a different scenario; in the first (stabilization period), the lysimeter was allowed to degrade naturally for about 50 days. Two litres of water were added, as moisture plays an important role in accelerating biochemical, chemical and physical processes in the landfill [Straub and Lynch, 1982; Fellner et al., 2009; Ehrig, 1983; Kylefors et al., 2003]. A high moisture content is essential for the biodegradation process, as it facilitates the redistribution of nutrients and microorganisms in the waste [Yuen et al., 2001]. Water is also required for leachate recirculation at the start of the process [Ritzkowski and Stegmann, 2003]. A leachate that was pre-heated to a maximum of $40{ }^{\circ} \mathrm{C}$ was recirculated once per week during this stage, as recirculation is considered one of the most important factors for providing moisture to the waste in order to improve the decomposition processes, accelerate reduction of the organic load, shorten the stabilization process and overcome the acid accumulation that normally occurs in the first stage [Ledakowicz and Kaczorek, 2004; Daniels et al., 2008; Abu Qdais and Alsheraideh, 2008].

In the second stage from day 51 to day 111 (simulating the dry season), the temperature in the lysimeter was set in the range of $20-21^{\circ} \mathrm{C}$ (room temperature) and no recirculation of leachate or rain simulations took place. In the third stage (simulating a wet season) from day 112 to day 202, leachate recirculation took place twice per week and rain simulation was based on the average daily record; the addition of water was the same as the actual amount of precipitation that infiltrated into the landfill body in the case study. The added water was calculated as: $1 / \mathrm{d}=$ mean monthly rainfall/mean rain days $\cdot$ surface area of the reactor (i.e. $0.13 \mathrm{~m}^{2} \cdot 0.5$ ) as the surface area of the lysimeter was $0.13 \mathrm{~m}^{2}$ and the amount of rainfall percolating through the landfill was assumed to be $50 \%$ in accordance with Sanphoti et al. [2006]; Petchsri et al. [2006]. Figure 3 represents the average rainfall in the vicinity of the El-Akader landfill, which is the biggest one in Jordan [Abu-Rukah, 2001]. These data were used in the experiment. In the final stage from day 203 to day 292, the dry climate was simulated. During this period, leachate was recirculated once per week to speed up the degradation process, the temperature was set to $38{ }^{\circ} \mathrm{C}$ and rainfall assumed to be $0 \mathrm{~mm}$. The simulation scenarios are presented in Table 1. 


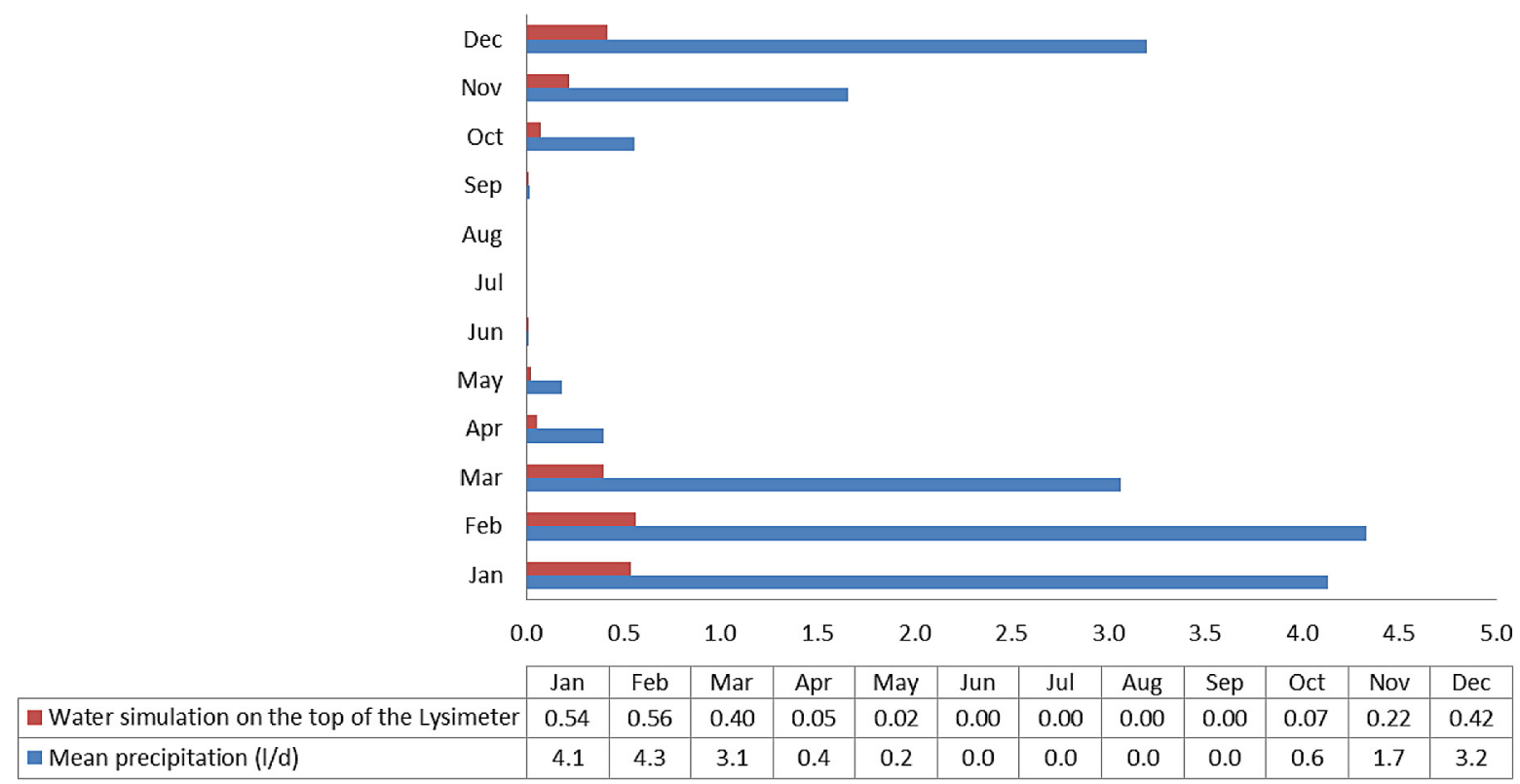

Figure 3. Precipitation data and water simulation on the top of the lysimeter $(1 / \mathrm{d})$

Table 1. Simulation scenarios

\begin{tabular}{|l|c|c|c|}
\hline \multicolumn{1}{|c|}{ Scenario } & Simulation time (days) & Temperature & Leachate recirculation (I/week) \\
\hline $1^{\text {st }}$ Stabilization period & 50 & $40^{\circ} \mathrm{C}^{* *}$ & $2^{*}$ \\
\hline $2^{\text {nd }}$ Dry season & $51-111$ & $28-32^{\circ} \mathrm{C}$ & 0 \\
\hline $3^{\text {rd }}$ Wet season & $112-202$ & $20-21^{\circ} \mathrm{C}$ & 2 \\
\hline $4^{\text {th }}$ Dry season & $203-292$ & $38^{\circ} \mathrm{C}$ & 1 \\
\hline
\end{tabular}

* 2 litres of heated tap water were added and removed to overcome acid accumulation and reduce the stabilization time in the lysimeter.

** Pre-heated leachate was recirculated.

\section{Analytical methods}

The representative MSW sample was prepared according to the standard quartering method for waste characterization and sampling, after which it was analysed for moisture content (MC). The leachate was measured and analysed once per week. Temperature (T), Electric Conductivity (EC), $\mathrm{pH}$, Nitrate $\left(\mathrm{NO}_{2}\right)$, Nitrite $\left(\mathrm{NO}_{3}\right)$ and Chloride $\left(\mathrm{Cl}^{-}\right)$were measured by means of $\mathrm{COD}$ and a Multiparameter Bench Photometer, HI 83099 (HANNA Instruments). The Nickel (Ni), Chromium $(\mathrm{Cr})$, Copper $(\mathrm{Cu})$, Iron $(\mathrm{Fe})$, Magnesium $(\mathrm{Mg})$, Sulfate $\left(\mathrm{SO}_{4}{ }^{2-}\right)$, Phosphate $\left(\mathrm{PO}_{4}{ }^{2-}\right)$ and Ammonium $\left(\mathrm{NH}_{4}+{ }^{-} \mathrm{N}\right)$ analyses were conducted using an ICP-OES Spectrometer, Optima 8300 (Perkin-Elmer). Redox potential was measured with a WTW redox electrode (MultiLine, IDS), while biological oxygen demand $\left(\mathrm{BOD}_{5}\right)$ was measured in an accredited laboratory (VASYD lab, Lund University). All leachate samples were passed through a $0.45 \mu \mathrm{m}$ membrane filter. Biogas vol- ume was measured using a Ritter volumetric gas meter and the composition analysed by means of an LFG 20 gas analyzer (ADC Gas Analysis Limited) in real time by monitoring Methane $\left(\mathrm{CH}_{4}\right)$, carbon dioxide $\left(\mathrm{CO}_{2}\right)$ and Oxygen $\left(\mathrm{O}_{2}\right)$ concentrations as well as the $\mathrm{MC}$ of the gas using a trap membrane filter $(0.45 \mu \mathrm{m})$.

\section{RESULTS AND DISCUSSION}

Figure 4 presents the cumulative gas production and the volumetric gas fraction for $\mathrm{CH}_{4}$ and $\mathrm{CO}_{2}$ after running the lysimeter for 292 days. Gas production was negligible during the acidogenic stage due to the degradation of the organic material, while residual oxygen was consumed within a short time. At the beginning of the methanogenic stage, the gas production increased. However, after 260 days, the gas and leachate production rates became negligible. The start of the anaerobic degradation process was clear; the acidogenic 
and methanogenic stages were observable both in the leachate and the gas composition, $\mathrm{CH}_{4}$ production increased and $\mathrm{CO}_{2}$ grew by up to $79 \%$ after 120 days and then dropped to $40 \%$ after a further 15 days, which can be considered the start of the methanogenic stage. However, the 160 day period from when $\mathrm{CH}_{4}$ was first detected until it formed $45 \%$ of the content of the waste demonstrated the slow growth of methanogens and risk of failure in cases where the organic load is high. Temperature also plays a significant role in the process. During the stabilization period ( $1^{\text {st }}$ stage $)$, the decomposition process was accelerated by heating the recirculated leachate to $40^{\circ} \mathrm{C}$ and gas production increased during the dry season ( $4^{\text {th }}$ stage). Methane production escalated when the lysimeter temperature was maintained at $35-38^{\circ} \mathrm{C}$, which agrees with the results presented by Khattabi et al., 2002; Abu Qdais and Alsheraideh, 2008. It is also well known that the MC significantly influences methane production in the $\mathrm{pH}$ range of 6.87.2 [Gurijala and Suflita, 1993]. A high landfill gas production rate was observed, which could be due to continuing decomposition of organic waste with a high MC from simulated rain and recycled leachate, which also agrees with the results of Gurijala and Suflita [1993]. The methane content was found to be more than (45\%), which clearly indicates the possible danger of explosion and fire in the landfill. Carbon dioxide and methane emissions have a significant impact on climate change. Only $\mathrm{CH}_{4}$ is accounted for in the estimation of $\mathrm{GHG}$ emissions from landfills, despite the global warming potential (GWP) of $\mathrm{CO}_{2}$ upon release [IPCC, 2007; IPCC, 2006]. This is due to the general consensus that $\mathrm{CO}_{2}$ from waste decomposition is of biogenic origin and hence does not add to the overall GHG emissions that contribute to global warming [Lou and Nair, 2009] also $\mathrm{CH}_{4}$ is a GHG that is 23 times more harmful than the same volume of $\mathrm{CO}_{2}$ on climate change [IPCC, 2007].

Figure 5 presents the cumulative gas production and the redox potential in the lysimeter study. The elevated carbon dioxide is caused by the beginning of biological decomposition. The acidogenic could be separated from the methanogenic stage due to the changed redox potential of the leachate together with the increase in methane production. The redox potential change from a positive to a negative value is considered a clear indication of the beginning of the methanogenic stage. Methane production indicates reducing conditions with a redox potential. Unlike carbon dioxide, the solubility of methane is poor in water. The acidogenic stage in the lysimeter lasted about 4 months, whereas it usually lasts for a few years in a full-scale landfill. The anaerobic conditions as well as leachate recirculation accelerated the process.

The leachate generated and the precipitation on the top of the lysimeter are presented in Figure 6. The moisture content (MC\%) was 52 in fresh and 43 in digested waste. The volatile solids (VS\%) were 45 in fresh and 32 in digested waste. The total solids (TS\%) were 48. Leachate generation increased after leachate recirculation and was higher than the volume of added tap water. In the wet season scenario, leachate generation increased due to precipitation and was 10.2, 14 and 15.71 after125, 175 and 200 days respectively. In the dry seasons, only a negligible amount of leachate was generated from waste degradation during stages 1 and 4, 2.5 and 2.4 , respectively.

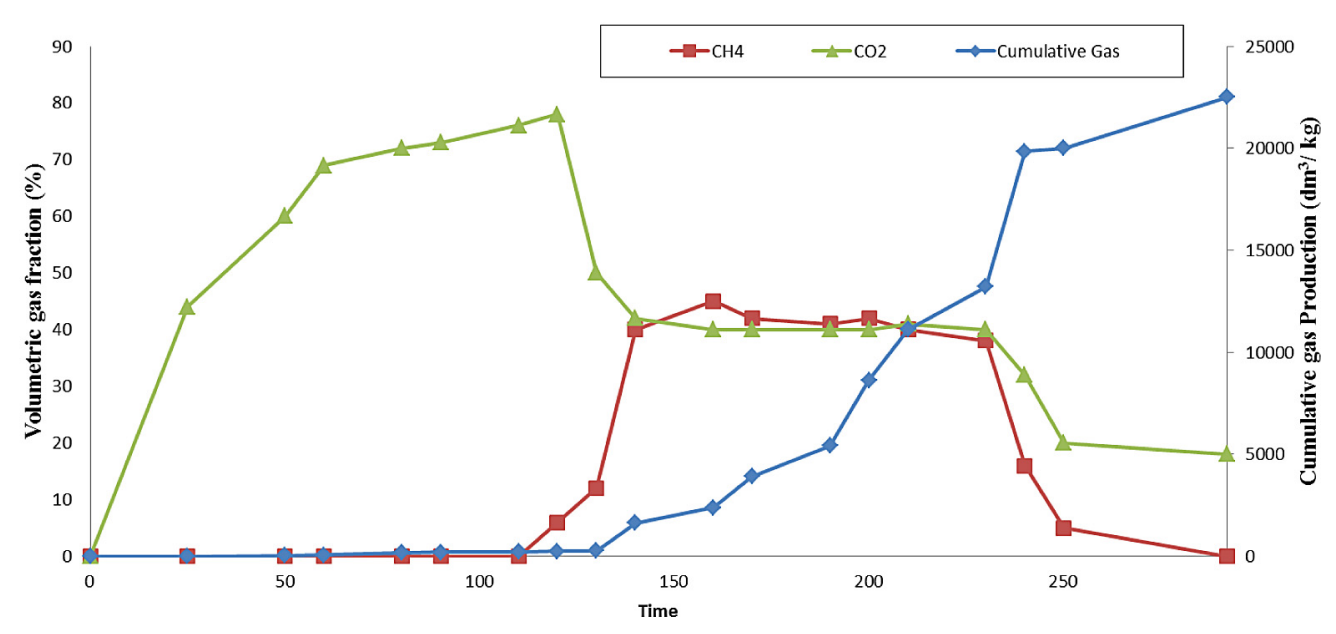

Figure 4. The cumulative gas production and the volumetric gas fraction for $\mathrm{CH}_{4}$ and $\mathrm{CO}_{2}$. 


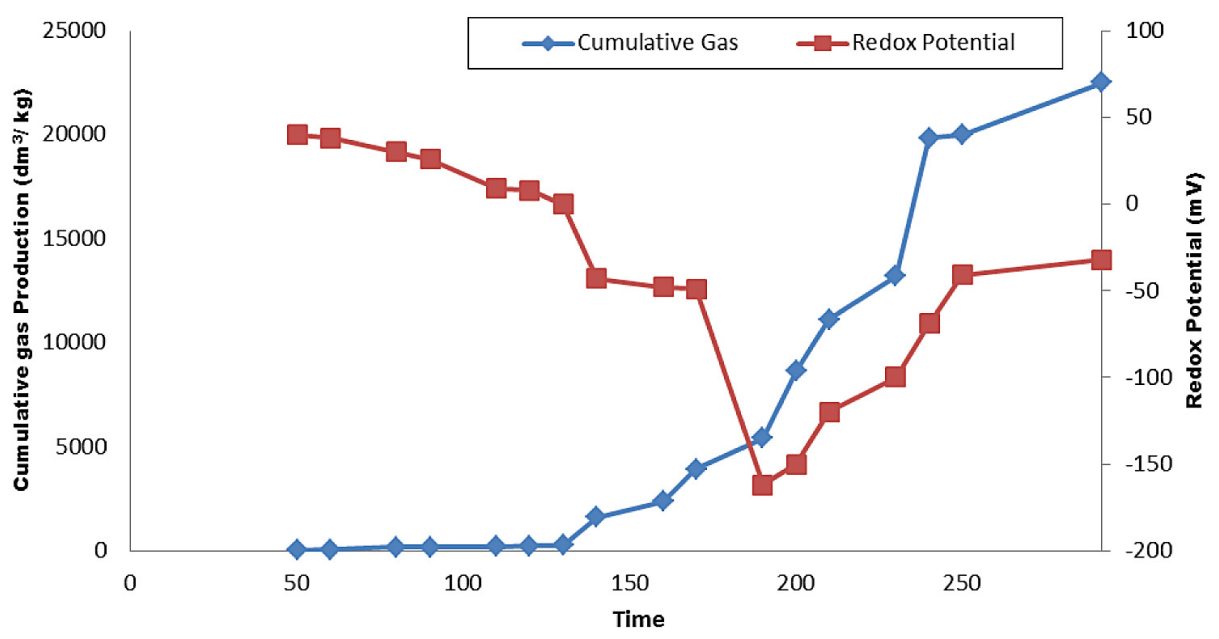

Figure 5. Cumulative gas production and redox potential changes

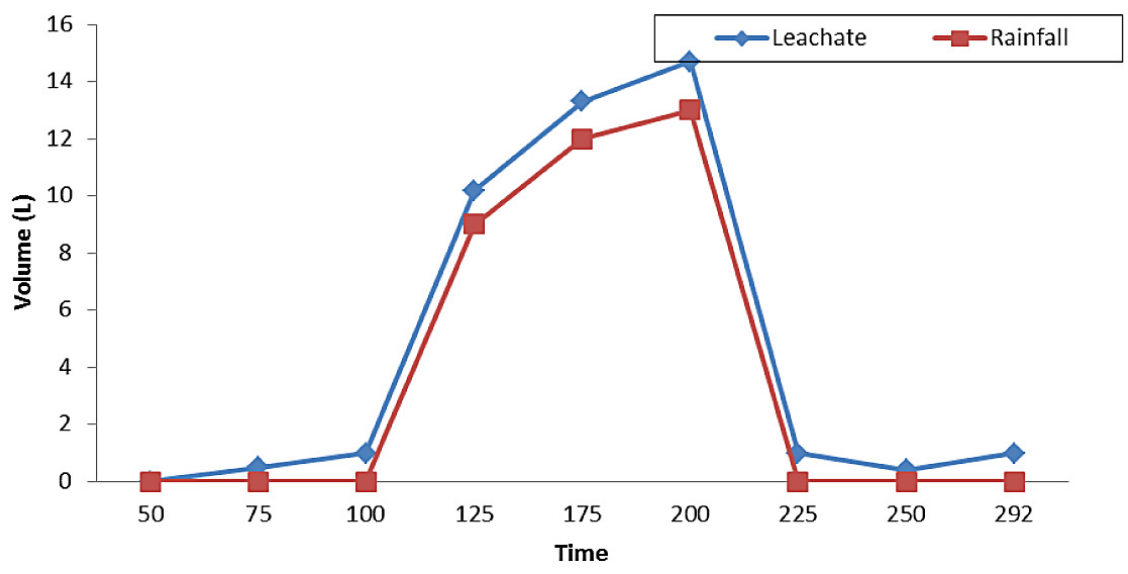

Figure 6. Leachate generation and precipitation on the top of the lysimeter

With precipitation (stage 3), the leachate amount was higher than in the scenarios without precipitation (stages 2 and 4), although the amount of leachate from waste decomposition was small throughout the experiments. This indicates that addition of water increases the MC of the waste to its field capacity, which allows leachate generation. In the above discussion it has been assumed that no landfill daily cover is used.

In Figure 7, the seasonal influence and the relation between the volumetric gas fraction $\left(\mathrm{CH}_{4}\right.$ and $\mathrm{CO}_{2)}$ and precipitation on the top of the lysimeter are presented. The gas composition illustrates the influence of temperature and leachate recirculation during the dry season, which enhanced biological activities leading to a sharp increase in $\mathrm{CO}_{2}$ to $70 \%$ during the first 50 days. In the rainy season scenario, $\mathrm{CH}_{4}$ production after four months increased from $0-45 \%$ in 20 days, which means that waste decomposition was much higher with moisture (precipitation and recirculation) than without, which concurs with the results of Gurijala and Suflita [1993] and Wintheiser [1996].

The $\mathrm{pH}$ changes in the generated leachate are presented in Figure 8 . The $\mathrm{pH}$ value plays a prominent role due to its influence on microbial activities. In the first period (0-110 days) during hydrolysis, acetogenic and acidogenic stages, a large amount of organic acids are produced, resulting in a drop in $\mathrm{pH}$ from $\mathrm{pH} 7$ to $\mathrm{pH} 4.9$ and the mobilization of metals and other dissolved materials, thereafter with the start of the methanogenesis it start slowly increasing to 7.5 until day 200 and remained stable in the 6-6.5 range until the end of the observation period. The replacement of recirculated leachate by tap water facilitated successful maintenance of optimal $\mathrm{pH}$ and help providing the optimum growth of the Methane microorganisms. The stability indicates the solubilisation of the majority of organic compounds. In general, optimum growth of the Methane microorganisms occurs in $\mathrm{pH}$ neutral waters with low range $\mathrm{pH}$ values from 6.7 to 7.5 [Chris- 


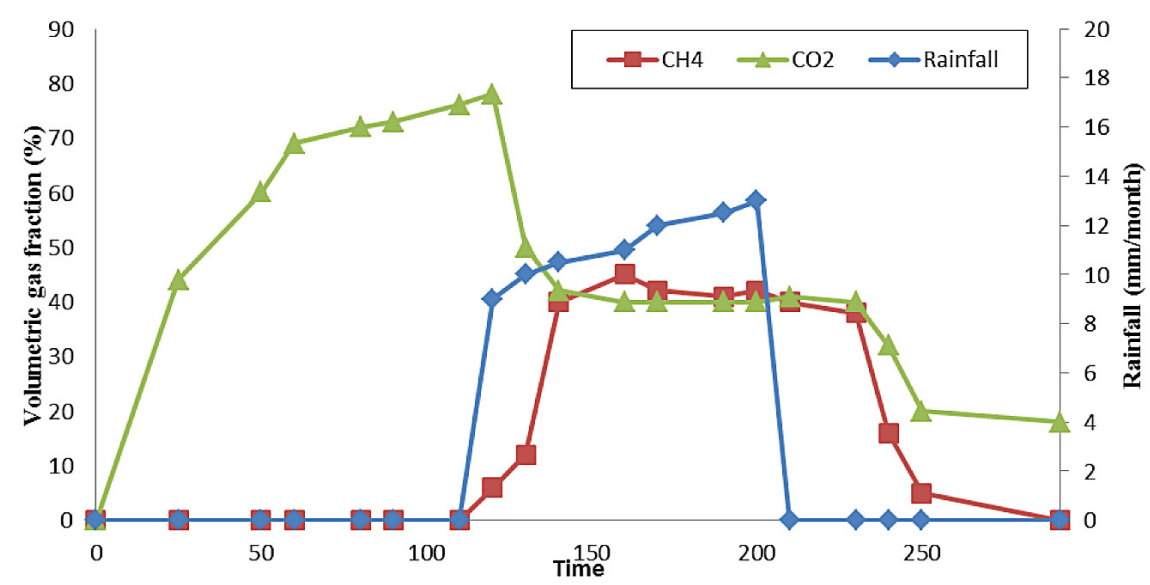

Figure 7. The relation between volumetric gas fraction $\left(\mathrm{CH}_{4}\right.$ and $\left.\mathrm{CO}_{2}\right)$ and precipitation on the top of the lysimeter

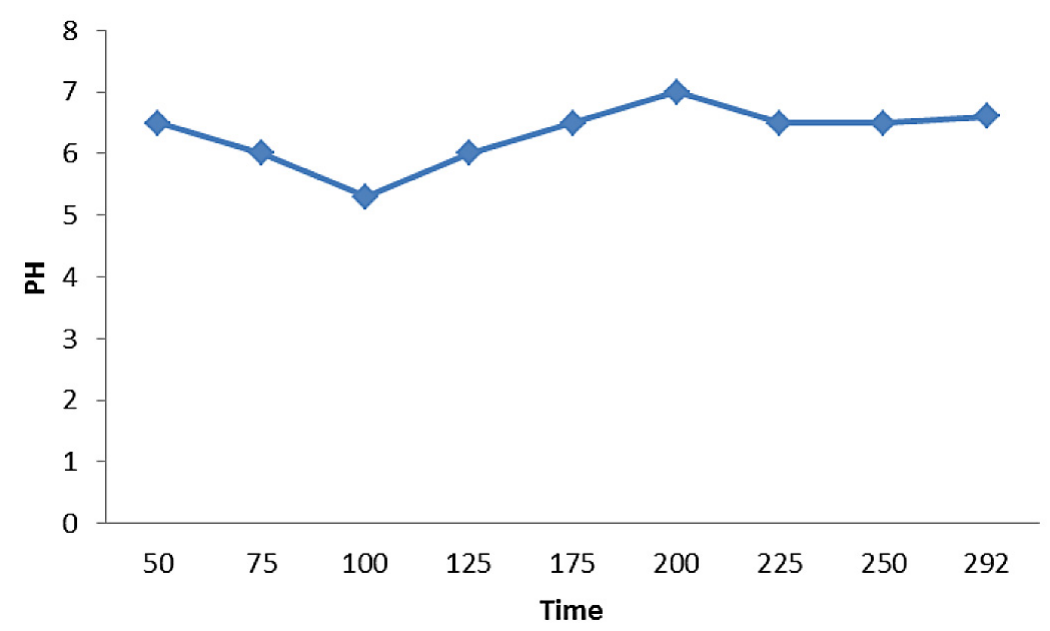

Figure 8. $\mathrm{pH}$ changes in the generated leachate

tensen et al., 1992; Chugh et al., 1999; Mace et al., 2003]. The ammonia produced by protein degradation helped to buffer the system. Howev$\mathrm{er}$, if the ammonia concentration increases the $\mathrm{pH}$ increases, it becomes toxic [Lien, 2004].

Figure 9 shows the COD concentration change in the leachate over time. The COD concentration increased from 28,000 to about 40,000 $\mathrm{mg} / \mathrm{l}$ in the first stage. When the washout from the lysimeter increases, it leads to a decrease in the COD-content, which is typical of both the hydrolysis and the acidogenesis stages. In the following stage, the biodegradable carbon compounds in the leachate were rapidly utilized for methane production and COD decreased from 40,000 mg/1 to $982 \mathrm{mg} / 1$. Leachate recirculation during the stabilization phase (day 0-50) contributed to better performance in terms of biological activity and methanogenesis. The influence of temperature in the stabilization and dry periods (day $0-111$ ) was notable. The temperature was set at $40{ }^{\circ} \mathrm{C}$ for the first 50 days, during which methane production in- creased from $0-40 \%$. The dry scenario increased biological activity and gas production, while in the wet scenario leachate generated grew from 1 to 12.71 , /depleting the water added during the stabilization period. These results correspond with the leachate concentration in Al-Russifa landfill, where the BOD-concentration was $36,900 \mathrm{mg} / \mathrm{l}$, the COD-concentration 157,900 mg/l [Mrayyan and Hamdi, 2006] and global values were from 150 to about $100,000 \mathrm{mg} / 1$ [Christensen et al., 1992]. Generally, leachate from new landfills has a high COD content until the methanogenic stage is established. Thereafter, the COD-content steadily declines over time and, due to washout, levels off after about 10 years [Akyurek, 1995].

In figure 10 the metal content in the leachate is presented. The heavy metal concentration usually refers to the total amount of dissolved metal. In MSW, heavy metals are mainly present in elemental forms, additives (often organic and inorganic salts) in polymers (e.g. plastics, textiles, leather, rubber, paper, etc.), batteries and various 


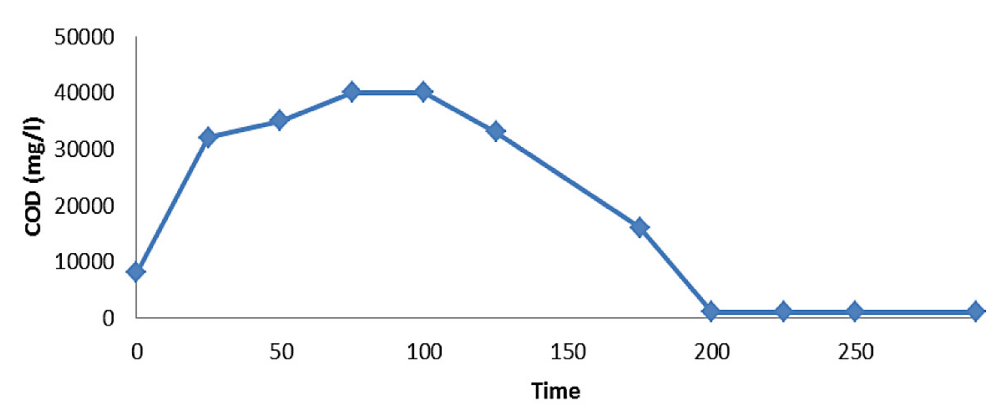

Figure 9. Chemical oxygen demand (COD)

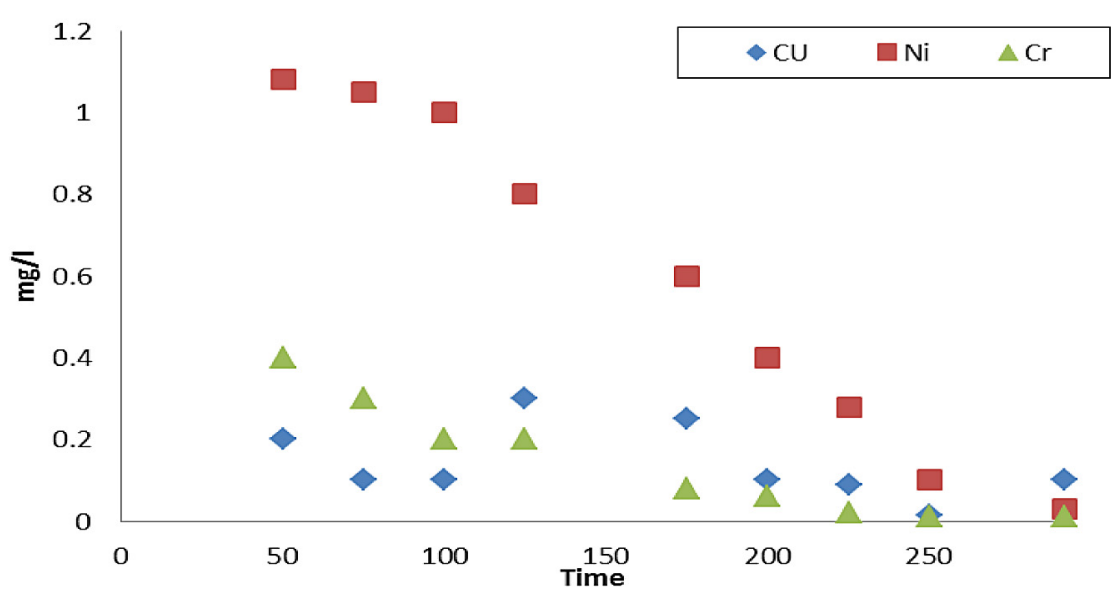

Figure 10. $\mathrm{Cu}, \mathrm{Ni}$ and $\mathrm{Cr}$ content in the leachate

complex solid phase matrices. The solubility of metals varies with $\mathrm{pH}$, the presence of complexation ligands and metal species. $\mathrm{Cu}, \mathrm{Cr}$ and $\mathrm{Ni}$ are dissolved by strong mineral acids, while elemental forms of $\mathrm{Cd}, \mathrm{Pb}$ and $\mathrm{Zn}$ can also be dissolved by a weak acid $(\mathrm{pH}=5)$. The concentration of metals in the leachate was high, 0.2, 1.08 and $0.4 \mathrm{mg} / \mathrm{l}$ for $\mathrm{Cu}, \mathrm{Ni}$, and $\mathrm{Cr}$ respectively during the stabilization and dry periods for 111 days and lower during the wet season for 202 days, when it decreased to $0.1,0.4$ and $0.06 \mathrm{mg} / \mathrm{l}$ for $\mathrm{Cu}, \mathrm{Ni}$, and $\mathrm{Cr}$ respectively. The heavy metal concentration in the leachate increased during the hot seasons and decreased in the wet season. It was probably affected by wash out and possibly also by the sorptive capacity of waste containing organic matters with neutral to high $\mathrm{pH}$ methanogenic leachate levels. The heavy metal ions generally have low solubility in the waste, but can be affected by the pH and redox potential [Salem et al., 2008]. The release of cadmium from plastics requires strong mineral acids, while $\mathrm{Cr}$ in leather can be released under weak acid conditions. Usually these metals are found at moderate concentration levels in municipal landfill leachate [Baun and Christensen, 2004]. Particle size plays an important role in the solubility of heavy metals [Prudent et al., 1996;
Flyhammar, 1998]. The environmental impact of landfills due to the dissolution of heavy metals requires long-term monitoring.

\section{CONCLUSIONS}

Determining the composition and generation of landfill emissions is important when assessing the feasibility of gas utilization and the leachate collection system at a landfill, but also when evaluating the potential for gas migration and leachate generation as an indication of landfill stability. A typical MSW sample reflecting the solid waste stream in Jordan was placed in an anaerobic lysimeter to simulate the influence of climate on the emission potential of landfills located in semi-arid regions. The experimental results revealed that a significant amount of leachate and landfill gas was produced during the wet season. The methane content was found to be more than $45 \%$ and the leachate produced amounted to 15.71 after 200 days. This could be due to continuous decomposition of the organic waste with a high MC from leachate recirculation coupled with precipitation. However, after day 260 the gas and leachate production rates became negligible. 
The leachate recirculation combined with precipitation led to a more rapid degradation due to accelerated biological stabilization and the start of the methanogenesis stage. In real landfills natural decomposition is slow and landfill daily cover minimizes the amount of precipitation penetrating the landfill body. The results indicate that current landfill practices as well as landfill design and operational methods in Jordan need to be adjusted to ensure sustainability. The first recommendation is to convert the biggest landfill to anaerobic bioreactors. The gas could then be utilized, which concurs with the country polices and with the most common worldwide mitigation strategy is the capture of landfill gas for flaring or combustion to recover energy, as it provides significant environmental, economic and energy benefits [EI-Fadel and Sbayti, 2000], when financially visible. The second recommendation is that in cases where landfill emissions cannot be collected or treated (small landfills), the landfill should be kept as dry as possible to minimize leachate production and reduce the risk of groundwater contamination. This can be achieved in the short without much additional investment by improving and controlling open dumping to reduce its adverse impact. This approach tends to delay decomposition due to lack of moisture, thus reducing the risk of long-term environmental impact when the landfill cover becomes less effective. Finally, if the landfill is kept open during the dry season, direct evaporation could have a significant impact on the amount of leachate produced in such climates. However, this recommendation is only applicable in cases where the landfill has a bottom liner in addition to a leachate collection and treatment system. This recommendation takes the climate change effect into account, as an analysis of available climate data (1961-2005) published by [UNDP, 2009] found an increase in maximum and minimum temperatures in selected meteorological stations of between $0 .{ }^{\circ} \mathrm{C}$ and $2.8^{\circ} \mathrm{C}$ at the same time as a $5-20 \%$ decrease in precipitation was reported by a majority of meteorological stations in Jordan. The projected climate data for the year (2050) indicates an increase in temperature of less than $2{ }^{\circ} \mathrm{C}$ [UNDP, 2009]. The results can be used as a primary reference for optimization of landfill design parameters and sustainable landfill operational scenarios based on the climate as well as financial and technical means of the country in question. The existence and continued need for landfills now and in the future cannot be denied.
Not all waste can be composted or recycled and a certain portion will inevitably have to be landfilled. Nevertheless, Jordan should aim to reduce the amount of waste produced and divert it to suitable waste management facilities. To ensure the success of such an approach, legislation should be implemented to bring about a significant reduction in the amount of waste deposited in landfill sites. Many waste streams should be pre-treated prior to final disposal and co-disposal of waste water prohibited at landfill sites. These changes could have a significant impact on the type and volume of leachate generated. Thereafter a gradual adoption of better designed landfills must be initiated to meet long-term sustainability goals. The pace will depend on the implementation of national policies and the availability of physical and financial resources. Finally, there is a clear need for more research on all aspects and to bear in mind that the composition of waste is extremely changeable due to its nature, length of time in the landfill and the effect of global warming.

\section{Acknowledgements}

The authors would like to thank the Åke och Greta Lissheds Stiftelse for the financial support.

\section{REFERENCES}

1. Abu-Rukah Y. 2001. The assessment of the effect of landfill leachate on ground-water quality-a case study. El-Akader landfill site-north Jordan. Journal of Arid Environments, 49, 615-630.

2. Abu Qdais H. and Alsheraideh A. 2008. Kinetics of solid waste biodegradation in laboratory lysimeters. Jordan Journal of Civil Engineering, 2(1), 45-52.

3. Aljaradin M. and Persson K.M. 2015. Numerical evaluation of different landfill daily cover in semiarid areas - Jordan. Int. J. Environment and Waste Management, 16(2), 95-110.

4. Akyurek M. 1995. Trends in landfill leachate characteristics. Eighteenth International Madison Waste Conference, Department of Engineering Professional Development, Madison.

5. Barlaz M., Ham R. and Schaefer D. 1989. Massbalance analysis of anaerobically decomposed refuse. Journal of Environmental Engineering, Asce, 115, 1088-1102.

6. Barlaz M., Milke M. and Ham R. 1987. Gas-production parameters in sanitary-landfill simulators. Waste Management \& Research, 5, 27-39.

7. Barlaz M.A., Schaefer D.M. and Ham R.K. 1989. Bacterial population development and chemical 
characteristics of refuse decomposition. In: A Simulated Sanitary Landfill. Applied and Environmental Microbiology, 55, 55-65.

8. Baun D. and Christensen T. 2004. Speciation of heavy metals in landfill leachate: A review. Waste Management \& Research, 22(1), 3-23.

9. Christensen T.H., Cossu R. and Stegmann R. 1992. Chemical and biological characteristics of landfill leachate. London and New York, Elsevier Applied Science.

10. Chugh S., Chynoweth D.P., Clarke W., Pullammanappallil P. and Rudolph V. 1999. Degradation of unsorted municipal solid waste by a leach-bed process. Bioresource Technology, 69, 103-115.

11. Daniels J.L., Ogunro V.O., Hilger H.H. and Schmader M.B. 2008. Laboratory-scale aerobic landfill bioreactor: A precursor to modeling and full-scale investigation. Waste Containment and Remediation.

12. Ehrig H.J. 1983. Quality and quantity of sanitary landfill leachate. Waste Management \& Research, 1, 53-68.

13. Ei-Fadel M. and Sbayti H. 2000. Economics of mitigating greenhouse gas emissions from solid waste in Lebanon. Waste Management \& Research, 18, 329-340.

14. Fellner J., Döberl G., Allgaier G. and Brunner, P.H. 2009. Comparing field investigations with laboratory models to predict landfill leachate emissions. Waste Management, 29, 1844-1851.

15. Flyhammar P. 1998. Use of sequential extraction on anaerobically degraded municipal solid waste. Science of The Total Environment, 212, 203-215.

16. Gurijala K.R. and Suflita J.M. 1993. Environmental factors influencing methanogenesis from refuse in landfill samples. Environmental Science and Technology, 27, 1176-1181.

17. IPCC 2006. Guidelines for National Greenhouse Gas Inventories. Prepared by the National Greenhouse Gas Inventories Programme, Eggleston H.S., Buendia L., Miwa K., Ngara T. and Tanabe K. (Eds) IGES. Japan.

18. IPCC 2007. Climate change 2007: Iimpacts, adaptation and vulnerability. Contribution of Working Group II to the Fourth Assessment Report of the Intergovernmental Panel on Climate Change. Cambridge University Press, Cambridge, UK.

19. Khattabi H., Aleya L. and Mania J. 2002. Changes in the quality of landfill leachates from recent and aged municipal solid waste. Waste Manag. Res., 20, 357-364.

20. Kylefors K., Andreas L. and Lagerkvist A. 2003. A comparison of small-scale, pilot-scale and largescale tests for predicting leaching behaviour of landfilled wastes. Waste Management, 23, 45-59.

21. Ledakowicz S. and Kaczorek K. 2004. Laboratory simulation of anaerobic digestion of municipal solid waste. Journal of Environmental Science and Health, Part A, 39, 859-871.

22. Lien N. 2004. Dry anaerobic digestion of municipal solid waste as pretreatment prior to landfills. EV-04-14. Master Thesis.

23. Lou X.F. and Nair J. 2009. The impact of landfilling and composting on greenhouse gas emissions: A review. Bioresource Technology, 100, 3792-3798.

24. Mace S., Bolzonella D., Cecchi F. and Mata-Alvarez J. 2003. Comparison of the biodegradability of the grey fraction of municipal solid waste of Barcelona in mesophilic and thermophilic conditions. Water Sci. Technol., 48, 21-28.

25. Mrayyan B. and Hamdi M.R. 2006. Management approaches to integrated solid waste in industrialized zones in Jordan: A case of Zarqa City. Waste Management, 26, 195-205.

26. Petchsri P., Towprayoon S., Chaiprasert P. and Nopharatana A. 2006. The effect of precipitation on municipal solid waste decomposition and methane production in simulated landfill bioreactor with leachate recirculation. Songklanakarin J. Sci. Technol., 28, 615-631.

27. Prudent P., Domeizel M. and Massiani C. 1996. Chemical sequential extraction as decision-making tool: Application to municipal solid waste and its individual constituents. Science of the Total Environment, 178, 55-61.

28. Ritzkowski M. and Stegmann R. 2003. Emission behavior of aerated landfills: results of laboratory scale investigations. In: Ninth International Waste Management and Landfill Symposium, Sardinia, Cagliari, Italy.

29. Salem Z., Hamouri K., Djemaa R. and Allia K. 2008. Evaluation of landfill leachate pollution and treatment. Desalination, 220, 108-114.

30. Sanphoti N., Towprayoon S., Ritzkowski M. and Stegmann R. 2006. Seasonal influence on emission behavior of simulated tropical landfill operated with leachate recirculation. The $2^{\text {nd }}$ Joint International Conference on "Sustainable Energy and Environment", Bangkok, Thailand.

31. Stegmann R. 1997. Description of laboratory scale method to investigate anaerobic degradation process taking place in solid waste. Sixth International Waste Management and Landfill Symposium, Sardinia, Cagliari, Italy.

32. Stessel R. and Murphy R. 1992. A lysimeter study of the aerobic landfill concept. Waste Management \& Research, 10, 485-503.

33. Straub W.A. and Lynch D.R. 1982. Models of landfill leaching: organic strength. Journal of the Environmental Engineering Division - ASCE, 108, 251-268. 
34. SWEEP 2010. Country profile on solid waste mangement situation. The Regional Solid waste Exchange Information and Expertise Network in Mashreq and Maghreb Countries.

35. Tränkler J., Visvanathan C., Kuruparan P. Tubtimthai O. 2005. Influence of tropical seasonal variations on landfill leachate characteristics - Results from lysimeter studies. Waste Manag., 25, 1013-1020.

36. UNDP 2009. Jordan second national communication to the United Nations framework convention on climate change (UNFCCC), Jordan Ministry of Environment, Amman.
37. Wintheiser P. 1996. Landfill gas and condensate generation rates in arid climates: A case study. In: Proceedings of $19^{\text {th }}$ Int. Madison Waste Conference. University of Wisconsin, Madison.

38. Youcai Z., Luochun W., Renhua H., Dimin X. and Guowei G. 2002. A comparison of refuse attenuation in laboratory and field scale lysimeters. Waste Management, 22, 29-35.

39. Yuen S.T.S., Wang Q.J., Styles J.R. and Mcmahon T.A. 2001. Water balance comparison between a dry and a wet landfill - A full-scale experiment. Journal of Hydrology, 251, 29-48. 